\title{
11
}

\section{Dating marine shell in 0ceania: Issues and prospects}

Fiona Petchey

\author{
Waikato Radiocarbon Dating Laboratory \\ School of Science and Engineering \\ University of Waikato \\ Hamilton \\ New Zealand
}

\section{Abstract}

Marine shell has several advantages for radiocarbon $\left({ }^{14} \mathrm{C}\right)$ dating in the Pacific - it is ubiquitous in archaeological sites, is easy to identify to the species level, and can often be related directly to human activity. Consequently, shells are one of the most commonly dated ${ }^{14} \mathrm{C}$ sample types within this region. The modelled marine calibration curve and associated regional offsets (known as $\Delta \mathrm{R}$ ) originally construct ed by Stuiver et al. (1986), have been widely accepted as the most accurate method for calibrating surface marine ${ }^{14} \mathrm{C}$ dates. The use of published values, however, is not straightforward because the surface ocean ${ }^{14} \mathrm{C}$ reservoir is variable both regionally and over time, and because of additional uncertainties with the reliability of some shell species due to habitat and dietary preferences. This paper presents an overview of $\Delta \mathrm{R}$ variability in Oceania and highlights areas of caution when using extant $\Delta \mathrm{R}$ values, and when select ing marine shell for ${ }^{14} \mathrm{C}$ dating. Particular attention is given to the Hawaiian archipelago where numerous $\Delta R$ values are available for evaluation and the influence of ocean currents, estuarine environments and geology is apparent.

Keywords: Marine reservoir; $\Delta \mathrm{R}$; marine shell; radiocarbon $\left({ }^{14} \mathrm{C}\right)$ dating; Oceania.

\section{Introduction}

A plant or animal that obtains carbon from a marine source (or reservoir) yields what is termed an 'apparent age'. The surface ocean (down to around $200 \mathrm{~m}$ depth) has an apparent ${ }^{14} \mathrm{C}$ age that is, on average, 400 years older than the terrestrial (atmospheric) reservoir. This is known as the marine reservoir effect, and is caused by a delay in the ${ }^{14} \mathrm{C}$ exchange between the atmosphere and ocean, and by the mixing of surface waters with upwelled, ${ }^{14} \mathrm{C}$-depleted deep ocean water (Stuiver et al. 1986:982). This reservoir effect is automatically corrected for when a marine shell conventional radiocarbon age (CRA) ${ }^{1}$ is calibrated using the modelled marine ${ }^{14} \mathrm{C}$ calibration curve (e.g. MARINE04: Hughen et al. 2004). The marine calibration curve represents a global average of the surface ocean ${ }^{14} \mathrm{C}$ as it changes over time. 
Local and regional deviations from this global average, however, complicate the calibration of marine samples. To account for this deviation a local correction factor, or $\Delta \mathrm{R}-$ the difference between the model led ${ }^{14} \mathrm{C}$ age of surface water and the actual ${ }^{14} \mathrm{C}$ age of surface water at that locality - needs to be applied to the calibration. This value can be calculated from contemporaneous terrestrial/marine archaeological samples, or from 'historic' marine samples collected prior to 1950, whose age of death is known precisely (i.e. annually banded corals, shells and/or otoliths of surface-dwelling fish) (e.g. Druffel et al. 2001, 2004; Dye 1994; Guilderson et al. 1998, 2000; Higham and Hogg 1995).

Samples for $\Delta \mathrm{R}$ research must conform to a number of prerequisites regardless of what marine proxy is chosen:

1. The sample must have been collected live, or the date of death independently validated.

For pre-1955 shells of known age, this can be by the presence of documentation, or the fleshy remains of an animal, or valves in articulation with the ligament present. For archaeological hells, food remains fulfil this requirement.

2. The location of collection must be known.

3. The sample must be identified to genus level, and the dietary and habitat preferences of that species must closely represent that of the reservoir being investigated (e.g. open ocean, estuarine, etc).

4. The date of collection must be known, and for historic proxies, the date of collection must be before 1955 (i.e. prior to detonation of thermonuclear devices). ${ }^{2}$

Presently, there is only a limited number of published $\Delta \mathrm{R}$ values for Oceania (see Table 1 for a list of $\Delta \mathrm{R}$ values from pre-1950 marine proxies), most of which are readily available from the Marine Reservo ir Database (http://radiocarbon.pa.qub.ac.uk/marine/). Unfortunately, for most of these values it is impossible to know if the prerequisites discussed above have been rigorously adhered to. In particular, a number of values have unknown collection dates and are of questionable live collection. There are fewer reliable $\Delta \mathrm{R}$ values from archaeological terrestrial/shell pairs due to problems of association, and these are not as easily accessible to researchers. 


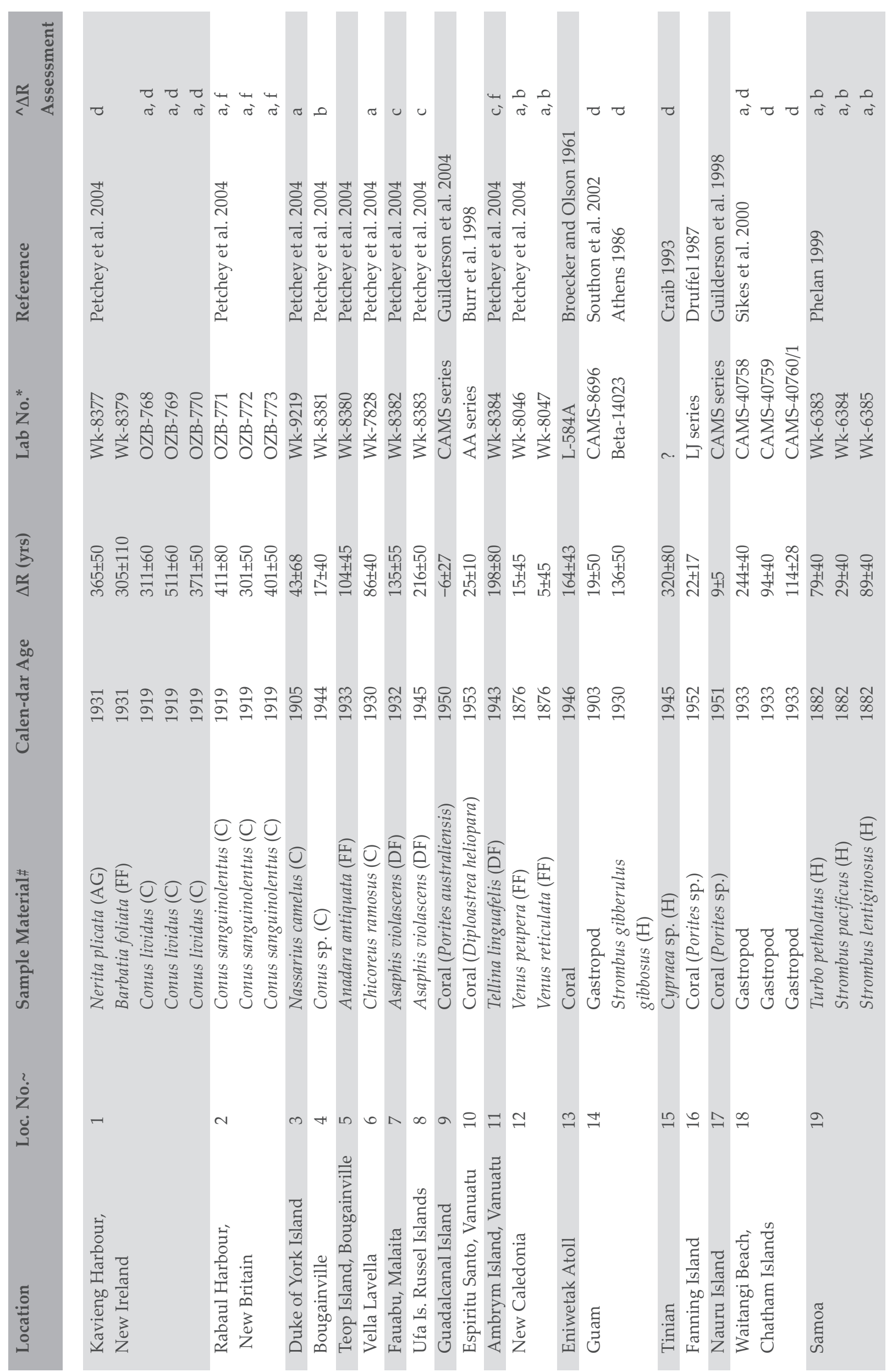




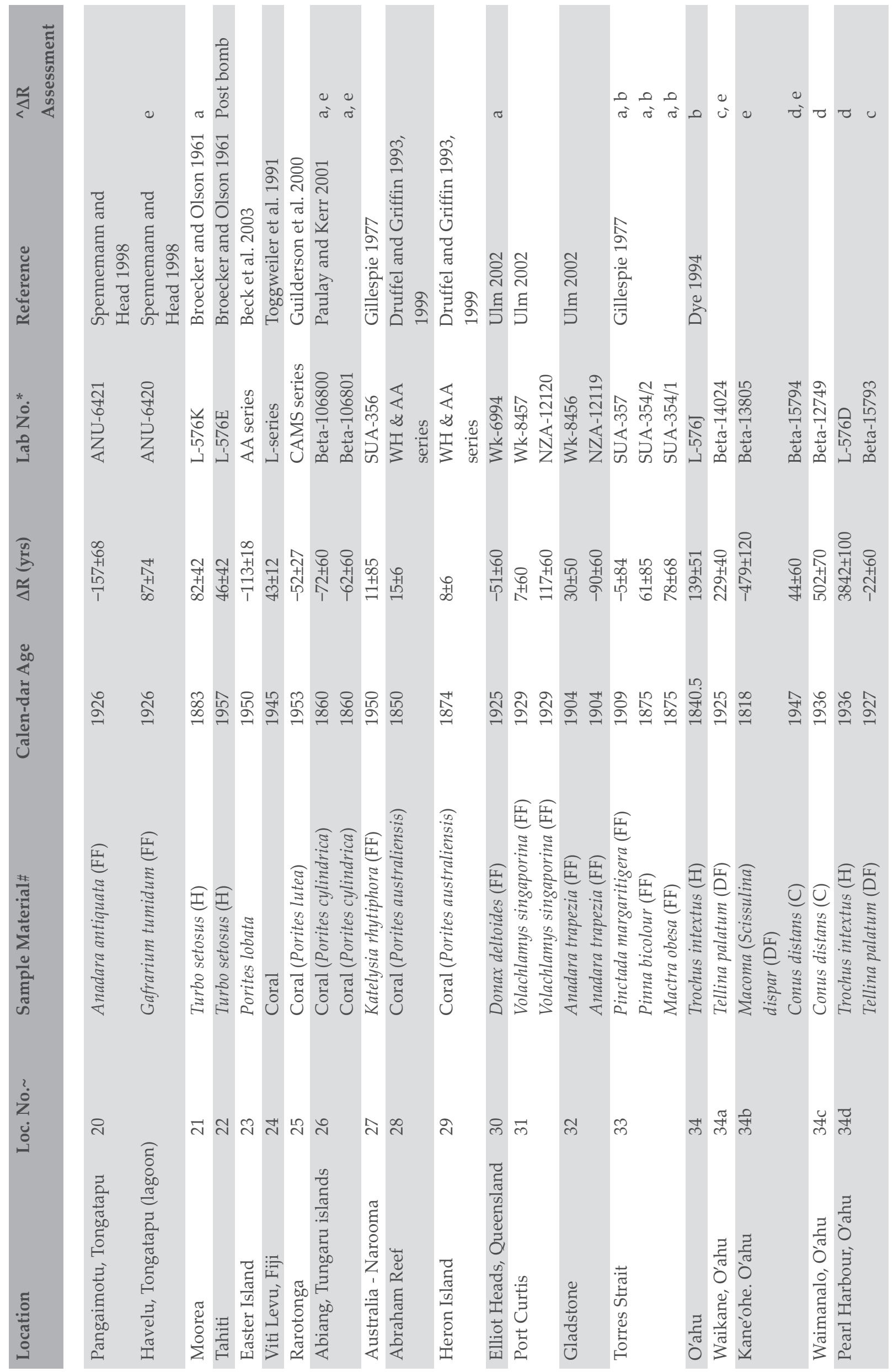




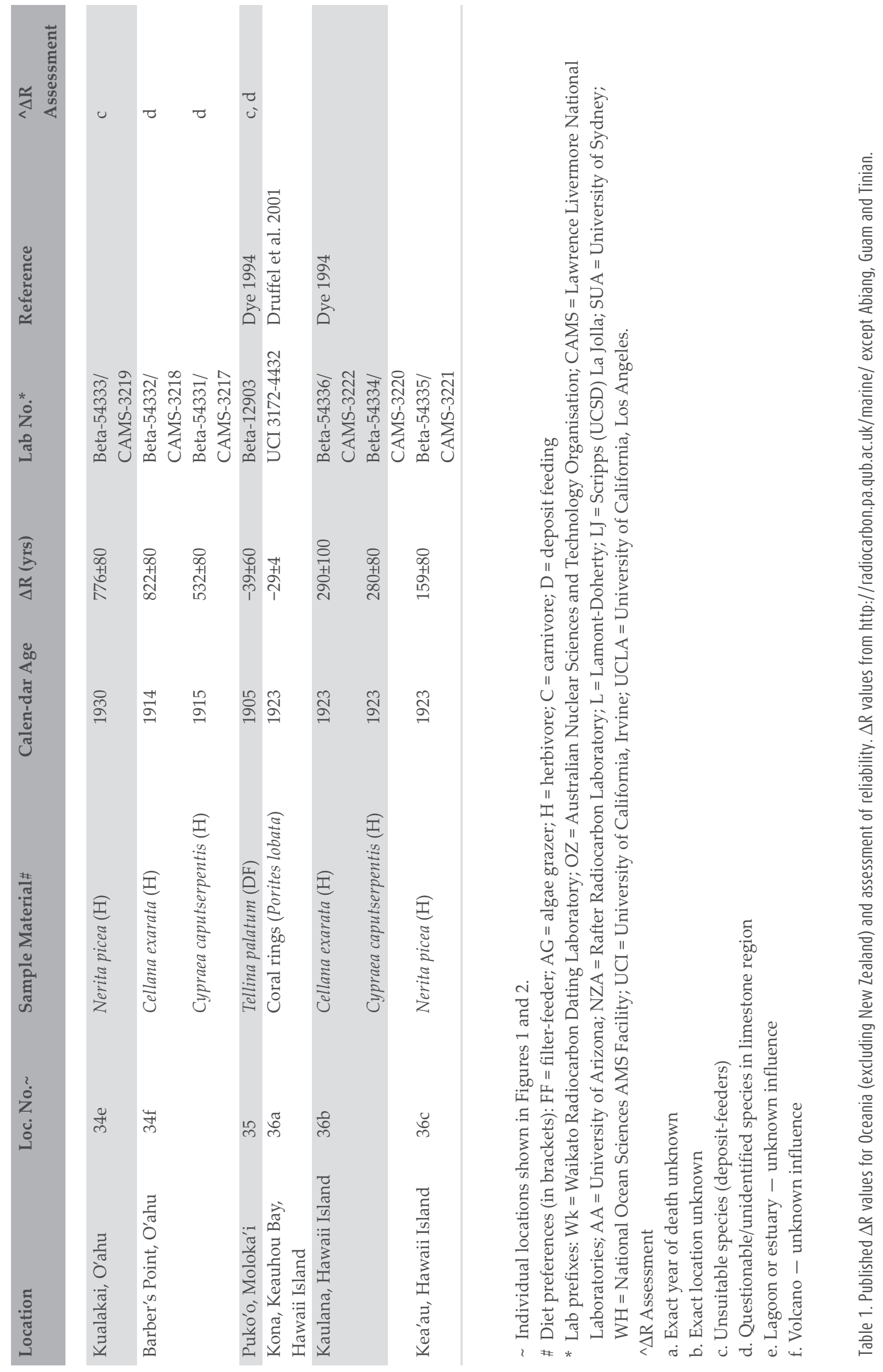


The limited available $\Delta \mathrm{R}$ values and lack of guidelines governing the selection of an appropriate $\Delta \mathrm{R}$ value for each island has been a continuing problem for the accurate calibration of dates on marine shell and other animals that subsisted on marine resources. This makes comparison of the chronology between, and sometimes within, archaeological sites difficult (e.g. Specht and Gosden 1997; Summerhayes 2001). Consequently, it is becoming increasingly important that researchers have an understanding of $\Delta \mathrm{R}$ variability and shellfish suitability for ${ }^{14} \mathrm{C}$ dating. This paper attempts to begin the process of addressing this problem and presents a discussion of $\Delta \mathrm{R}$ variability in Oceania, here defined as Melanesia, French Polynesia, Polynesia, East Coast of Australia and Micronesia. $\Delta \mathrm{R}$ values from New Zealand are not included. An assessment of reliability for each $\Delta R$ value is given in Table 1 and discussed in more detail below.

\section{Identification and diet}

It is widely recognised that shellfish selected for ${ }^{14} \mathrm{C}$ dating and $\Delta \mathrm{R}$ research must be identified to species level, and the dietary and habitat preferences of that species known. In particular, algae grazers $^{3}$ and deposit-feeders may have anomalously high $\Delta R$ values caused by the digestion of detritus in areas dominated by limestone geologies (Anderson et al. 2001; Dye 1994). Even in areas where limestone is absent, ${ }^{14} \mathrm{C}$ dating of deposit-feeding species has resulted in anomalous ${ }^{14} \mathrm{C}$ values due to the consumption of carbon from a terrestrial source (e.g. Hogg et al. [1998] recorded unusual values for Macomona liliana which can switch between filter-feeding and deposit-feeding modes depending on the environment [Beesley et al. 1998:343]). Despite these findings, deposit-feeding species regularly continue to be dated, potentially to the detriment of reliable ${ }^{14} \mathrm{C}$ chronologies. Limited data are available for carnivorous shellfish, but they are presumed to show an averaging effect depending on the carbon reservoirs of their prey, and could therefore be subject to similar uncertainties.

Petchey et al. (2004) noted anomalous $\Delta R$ values for deposit-feeding species from Ufa Island (Table 1, location 8), Malaita (location 7) and Ambrym Island (location 11), all of which are either limestone islands, or located near limestone deposits. The use of unsuitable shell species is also partly responsible for the range of $\Delta \mathrm{R}$ values available for the Hawaiian Islands (locations 34,35 and 36). Of the 14 pre-1955 marine shells reported by Dye (1994), 12 are of herbivorous or deposit-feeding shellfish and have a $\Delta R$ range of $-479 \pm 120$ yrs to $3842 \pm 100 \mathrm{yrs}$. Of these, Dye identified only three as coming from Pleist ocene limestone coastlines (locations $34 \mathrm{f}$ and $34 \mathrm{e}$ ) resulting in anomalously high $\Delta \mathrm{R}$ values of $822 \pm 80 \mathrm{yrs}$, $532 \pm 80 \mathrm{yrs}$ and $776 \pm 80 \mathrm{yrs}$. The value of $3842 \pm 100 \mathrm{yrs}$ for one of the two shell samples from Pearl Harbour (location 34d) was considered by Dye (1994:51) to be anomalous and possibly the result of hydrocarbon contamination. The use of a fossil shell from the nearby limestone is also a possibility. Dye did not notice small pockets of limestone on the eastern coast of O'ahu at Waimanalo (Figure 2a, location 34c), which could be responsible for the $\Delta \mathrm{R}$ of $502 \pm 70$ yrs for Conus distans, a carnivorous gastropod. Similarly, a $\Delta \mathrm{R}$ value of $229 \pm 40 \mathrm{yrs}$ for the deposit-feeding Tellina palatum from Waikane at the northern end of Kaneohe Bay (Figure 2a, location 34a) is suspect since Kapapa and Kekepa Islands located within the bay are consolidated dunes consisting of sand from ancient limestone (Stearns 1938).

Suspension-feeders (or filter-feeders) are usually considered the most reliable shells for ${ }^{14} \mathrm{C}$ dating because they consume suspended phytoplankton and dissolved inorganic carbon from seawater, and therefore more closely reflect the ${ }^{14} \mathrm{C}$ content of the surface ocean (Forman and Polyak 1997:888). Some bivalve species will, however, also engage in deposit-feeding activities depending on local circumstances (Snelgrove and Butman 1994). Moreover, suspension-feeding species may give anomalous $\Delta R$ values because of a hardwater effect where calcium carbonate from calcareous strata of disparate age becomes incorporated into the shell of animals that inhabit environs nearby (Spennemann and Head 1998). The incorporation of riverine material especially in estuarine environments (Dye 1994; Ingram 1998; Southon et al. 2002), and localized hydrothermal activity are also considerations. The effect of these varying sources of ${ }^{14} \mathrm{C}$ on shellfish will depend upon the degree of water exchange with the open ocean coupled with the specifics of habitat and geology (Hogg et al.1998; Tanaka et al. 1986). 


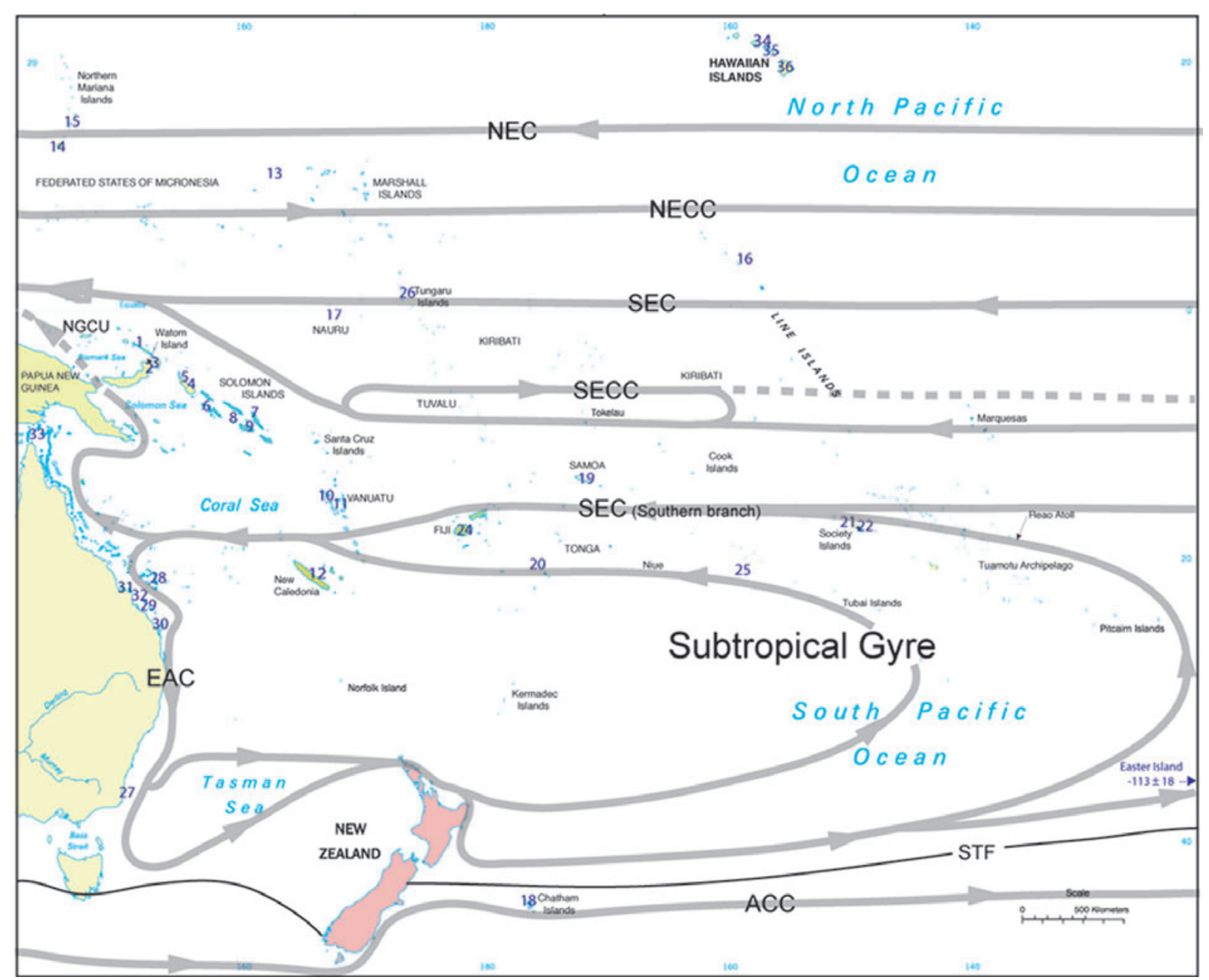

Figure 1. Map showing location of $\Delta R$ values given in Table 1 and major oceanic currents within 0ceania. Oceanic currents: STF = Subtropical Front; SECC = South Equatorial Counter Current; SEC = South Equatorial Current; NECC = North Equatorial Counter Current; $\mathrm{NEC}=$ North Equatorial Current; EAC = East Australian Current; NGUC = New Guinea Coastal Undercurrent; ACC = Antarctic Circumpolar Current (after Tomczak and Godfrey 2001:111).

\section{Geographic location and oceanic variability}

The ${ }^{14} \mathrm{C}$ of the surface ocean may also deviate from the modelled marine curve of Hughen et al. (2004) because of variations in upwelling and ocean currents (Stuiver and Braziunas 1993). The South Pacific islands are encircled by the South Pacific Gyre, which is driven by the high latitude eastward-flowing Antarctic Circumpolar Current and the mid latitude westward-flowing South Equatorial Current (SEC) (Figure 1). Coral core records collected over the last 20 years have enabled researchers to build a picture of ocean circulation and ${ }^{14} \mathrm{C}$ variation. Data collected from corals in tropical surface waters, such as the Galapagos Islands tend to have higher $\Delta \mathrm{R}$ values due to upwelling of old ${ }^{14} \mathrm{C}$-depleted waters (Druffel 1987). Lower $\Delta \mathrm{R}$ values have been recorded from southern subtropical waters (e.g. Rarotonga (Table 1 , location 25): $\Delta \mathrm{R}=-52 \pm 27 \mathrm{yrs}$ ) and have been attributed to high air-sea ${ }^{14} \mathrm{C}$ exchange and reduced mixing with older subsurface waters (Guilderson et al. 2000). Mixing of water from tropical and subtropical sources appears to result in midrange $\Delta R$ values as seen at Nauru (location 17: $\Delta R=9 \pm 5 \mathrm{yrs}$ ), Guadalcanal Island (location 9: $\Delta R=-6 \pm 27 \mathrm{yrs}$ ), Fiji (location 24: $\Delta \mathrm{R}=43 \pm 12 \mathrm{yrs}$ ), and the Great Barrier Reef (location 28: $\Delta \mathrm{R}=15 \pm 6 \mathrm{yrs}$; and location $29: \Delta \mathrm{R}=8 \pm 6 \mathrm{yrs}$ ). There are currently too few ${ }^{14} \mathrm{C}$ values to 
effectively evaluate the true extent or cause of $\Delta \mathrm{R}$ variability in the Oceania region, but there is enough data from specific locations within the Pacific to highlight the degree of potential variation possible over relatively small areas.

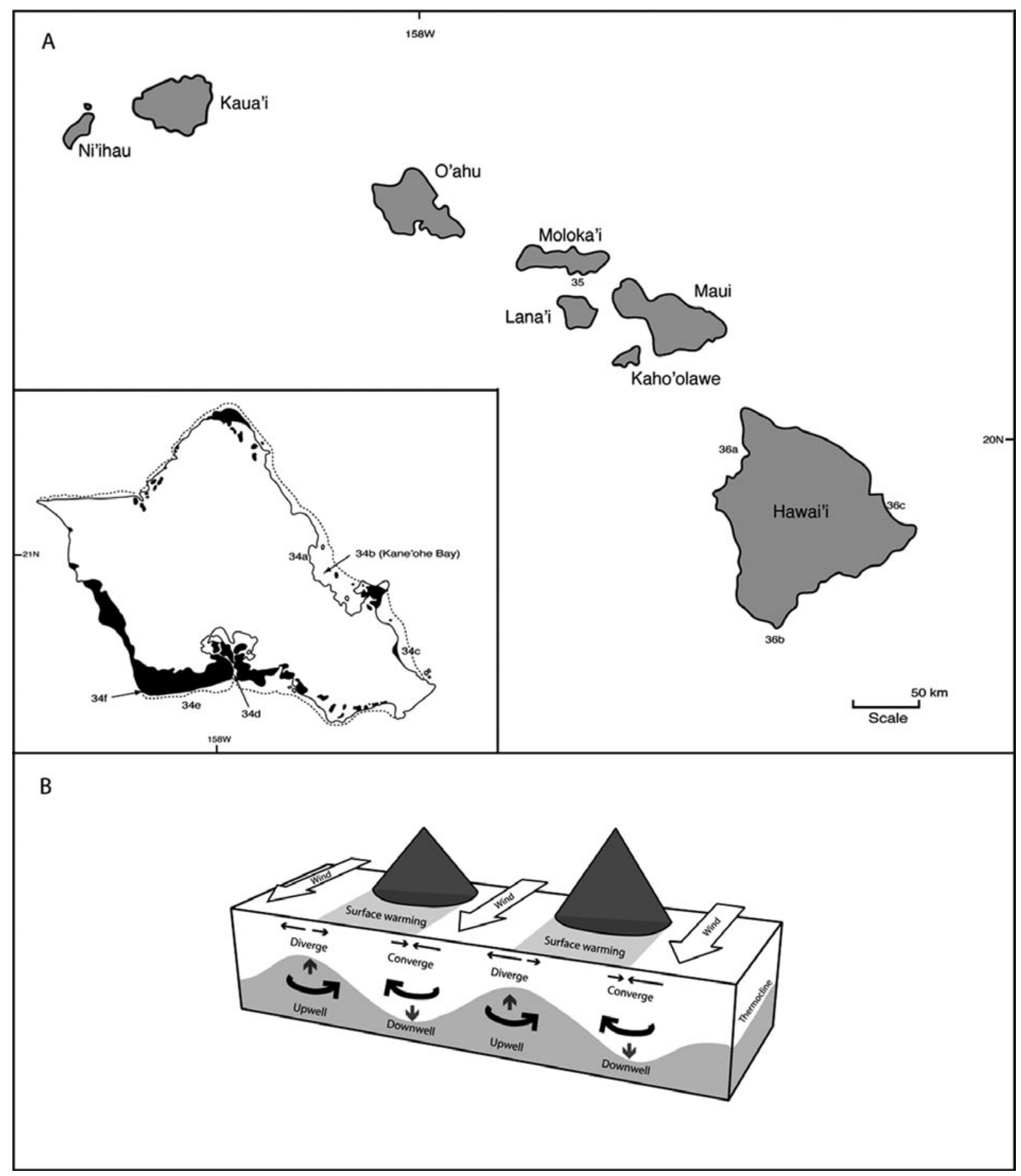

Figure 2. A. Map of the Hawaiian Islands showing places mentioned in the text (Insert: Limestone outcrops around 0'ahu [after Stearns 1978]). B. Conceptual diagram of upwelling around the Hawaiian archipelago (from Flament et al. 1996: Plate 10). 
To the western edge of the study area, seasonal interaction between the New Guinea Coastal Undercurrent, the SEC, and the North Equatorial Counter Current resulted in high reservoir values for shells from Watom Island $(\Delta \mathrm{R}=261 \pm 101$ yrs derived from marine/terrestrial archaeological material $)$ and New Ireland (Table 1, location 1: $\Delta R=365 \pm 50$ yrs and $305 \pm 110 \mathrm{yrs}$ ) that are indicative of upwelled ${ }^{14} \mathrm{C}$ depleted water (Figure 1). A $\Delta \mathrm{R}$ value of $43 \pm 68 \mathrm{yrs}$ for the Duke of York Islands (location 3), less than $40 \mathrm{~km}$ from Watom Island, is closer to other values recorded for the Coral and Solomon Seas. In this instance, it was hypothesised that the New Guinea Coastal Undercurrent brought higher ${ }^{14} \mathrm{C}$ waters from the Coral and Solomon Seas into the channel between New Britain and New Ireland, shielding the Duke of York Islands from the effects of the upwelling noted above (Petchey et al. 2004, 2005).

The east coast of Australia is likely to be just as complex. On approaching Australia the southern branch of the SEC bifurcates near $18^{\circ} \mathrm{S}$ with the southern flow feeding the East Australian Current while the northern flow continues northwards along the Great Barrier Reef. This northern flow is suppressed during the summer monsoon season (Tomczak and Godfrey 2001:119) and when combined with ENSO El Niño/Southern Oscillation events (interannual fluctuations in atmospheric and oceanic circulation that occur every two to ten years), shifts in $\Delta \mathrm{R}$ over relative short periods of time can occur (e.g. coral from the Abraham Reef returned a $\Delta R$ of -36 yrs in 1851 compared with 83 yrs in 1865) (Druffel and Griffin 1999: $23,610)$. It seems probable that these factors are partly responsible for the range of 'open ocean' values ( $-90 \pm 60 \mathrm{yrs}$ to $30 \pm 50 \mathrm{yrs}$ ) for the east coast of Australia (Table 1, locations 28, 29, 30 and 32).

Further south, the Chatham Islands (Table 1, location 18) are located within the Subtropical Front (STF). At the STF, there is a transition from mixed Subtropical to ${ }^{14} \mathrm{C}$-depleted Sub Antarctic Surface Waters (Heath 1985:87; Sparks et al. 1992:729). The high $\Delta \mathrm{R}$ values recorded for the Chatham Islands (244 \pm 40 yrs to $94 \pm 40 \mathrm{yrs}$ ) are typical for regions where ${ }^{14} \mathrm{C}$ depleted water from the deep ocean is upwelled (Stuiver and Braziunas 1993; Toggweiler et al. 1991). Unfortunately, limited information is published about these shells, and additional complications of habitat and diet are likely since they were collected from an area dominated by limestone and peat. A wide fluctuation in $\Delta \mathrm{R}$ values is possible in areas of up welling which means ${ }^{14} \mathrm{C}$ ages of shell samples from islands in these areas will be difficult to interpret. Data collected from an AD 1760-1771 coral core from Urvina Bay on the west coast of Isabela Island (Galapagos Islands) has presented the most dramatic example of seasonal and yearly ${ }^{14} \mathrm{C}$ variability known in the Pacific (Druffel et al. 2004). Higher ${ }^{14} \mathrm{C}$ values were found during January through March, when upwelling was weak or absent, while low values were obtained mid year during strong upwelling - when the southeast trade winds are the strongest. The extreme range in $\Delta R$ values fell at $314 \pm 44 \mathrm{yrs}$ in 1765 compared to a value of $26 \pm 4$ yrs five years later (Druffel et al. 2004:628).

A wide range in $\Delta R$ values is also recorded for the Hawaiian archipelago (Table 1). While this variation can be partly explained by the diets of the shellfish selected (see above), unique oceanic conditions that occur around the islands may also be responsible. Northeasterly trade winds flowing through the Hawaiian Islands result in a distinct pattern of upwelling and downwelling in the lee of the islands (Figure 2b) (Flament et al. 1996). Additional complications are caused by the presence of eddies that are generated in the lee of the islands as they impinge on the North Equatorial Current. These conditions create an eastward ocean current (the Hawaiian Lee Counter Current) in the lee of the Big Island that draws warm water from the Asian coast $8000 \mathrm{~km}$ away. In response, a cold tongue of upwelled water emanates from the southern tip of the Big Island and extends westward (Xie et al. 2001).

If the available $\Delta \mathrm{R}$ information for the Hawaii archipelago is reviewed with these observations in mind, a pattern emerges. Coral samples from Kona on the western coast of the Big Island (Figure 2a, location 36a: $\Delta \mathrm{R}=-29 \pm 4 \mathrm{yrs}$ ) come from a sheltered area in the lee of the island where water is being dow nwelled (Druffel et al. 2001:17). Conversely, samples from Kaulana on the southern tip of the island (location $36 \mathrm{~b})(\Delta \mathrm{R}=290 \pm 100 \mathrm{yrs}$ and $280 \pm 80 \mathrm{yrs})$ will have been subject to different oceanic conditions. Given the volcanic nature of the island (i.e. no limestone) these high values appear to be indicative of upwelling of ${ }^{14} \mathrm{C}$-depleted cold water in keeping with the observations mentioned above. The picture for $\mathrm{O}^{\prime}$ ahu is not as clear because of the presence of Pleistocene-age limestone and the diets of the shell species selected for $\Delta R$ (Table 1), but post-1970 coral core data from Kahe Point on the leeward side of 
O'ahu Island has also been considered to support downwelling (Druffel 1987:679). It seems likely, therefore, that $\Delta \mathrm{R}$ values for Hawaii will be highly variable depending on the coast in question. This may also be true for other island locations, though eddies and wakes are not normally as large as those present around Hawaii. One area that may be similarly complex is the southeast coastline of Australia. Here, large scale eddies form at the boundary between warm water of the Coral Sea and the cooler water of the Tasman Sea (Tomczak and Godfrey 2001:126-128). Unfortunately, no data is currently available along this coastline for analysis.

A high level of spatial control is also vital when dating shells from within lagoons. The $\Delta \mathrm{R}$ value of shells from atoll lagoons will depend on the rate of exchange between the lagoon and the open ocean waters, which is dependant on the number of channels (hoas) as well as their depth and orientation with respect to the prevailing sea swell. The 'residence time' is used to characterize the length of time it takes for water to exchange between the lagoon and the open sea. Throughout the five archipelagos that comprise French Polynesia the residence times of atolls and lagoons vary from five hours to 230 days (Charpy 2002). Consequently, it is possible for the $\Delta R$ to vary considerably. Radiocarbon dating of live corals collected from within the lagoon of Reao Atoll (eastern Tuamotu Archipelago) by Pirazzoli et al. (1987:66) suggested a ${ }^{14} \mathrm{C}$ activity that was in equilibrium with the atmosphere, while shells collected from the outer reefs were in equilibrium with sea water (an apparent difference in CRA of $440 \pm 70 \mathrm{yrs}$, equivalent to a near $0 \Delta R$ ). Conversely, Paulay and Kerr (2001:1197-8) suggested that the local reservoir ef fect for the Tarawa Atoll - part of the Tungaru Islands - was 'inconsequential' on the basis of ${ }^{14} \mathrm{C}$ measured from two specimens of Porites cylindrica collected in the 1860s from nearby Abaiang Atoll (Table 1, location 26). It is possible, however, that $\Delta \mathrm{R}$ values for the two atolls may not be comparable since the residence time of Tarawa Atoll has been calculated at around one week (Chen et al. 1995), whereas Abaiang Atoll has more restricted water exchange with the open ocean as well as an influx of freshwater to the south (Smith 1999).

In areas of limited exchange with the open ocean, geology may also play an important role in determining the reservoir value of filter-feeding shellfish, and a hardwater effect may occur in areas where limestone dominates the bedrock. This has been suggested for shellfish collected from Tongatapu (Table 1, location 20). Tongatapu is a raised volcanic atoll with a Pleistocene limestone capping, and an internal lagoon separated from the ocean by a complex system of reefs and channels. $A \Delta R$ of $87 \pm 74$ yrs for Gafrarium tumidum a filter feeding bivalve - from within Havelu lagoon was attributed to a hardwater effect caused by evaporation that resulted in ground water discharge into the lagoon, compounded by a long mean residence time of 31 days (Spennemann and Head 1998:1049-50). Conversely, the low $\Delta \mathrm{R}$ value of $-157 \pm 68 \mathrm{yrs}$ for the nearby islet of Pangaimotu was considered by Spennemann and Head (1998) to represent ${ }^{14} \mathrm{C}$ values for the open ocean. This value appears, however, to be unusual when compared to other published open ocean values in this area (though a similar value is recorded for Porites lobata for Easter Island: $\left.\Delta R=-113 \pm 18 \mathrm{yrs}^{4}\right)$. A possible alternative suggestion is enrichment in ${ }^{14} \mathrm{C}$ caused by wind and wave action, because the reef flat surrounding Pangaimotu is exposed regularly at low tide and water is less than $2 \mathrm{~m}$ deep (Richmond and Roy 1986). Forman and Polyak (1997:888) have argued that increased wind turbulence may augment transfer of enriched ${ }^{14} \mathrm{CO}_{2}$ from the atmosphere reducing the reservoir effect (and result in a negative $\Delta \mathrm{R}$ value) by 100 to 200 years. A similar explanation has been given to enriched ${ }^{14} \mathrm{C}$ values for shellfish growing in the open marine inter- tidal zone of Tairua Harbour, New Zealand (Hogg et al. 1998).

Estuarine reservoirs are also potentially complex due to the interaction and incomplete mixing of ${ }^{14} \mathrm{C}$ from both terrestrial and marine reservoirs (Ulm 2002:322). This is especially problematic where circulation is restricted. Kaneohe Bay, O'ahu Island (Figure 2a: location 34b) has a deep lagoon between an outer reef and the shore. To the southeast of the bay low wave energies have enabled the streams entering the bay to form small deltas (Bathen 1968; Moberly 1963:31). The range of $\Delta \mathrm{R}$ values for Kaneohe Bay includes $44 \pm 60$ yrs for a sample of Conus distans, 229 \pm 40 yrs for a sample of deposit-feeding Tellina palatum (see discussion above), as well as a low $\Delta \mathrm{R}$ value of $-479 \pm 120 \mathrm{yrs}$ for a sample of Macoma (Scissulina) dispar. Macoma dispar is commonly found in areas of freshwater discharge (Dye 1994:52) 
and the low $\Delta \mathrm{R}$ value is likely to be caused by the incorporation of river-borne dissolved and particulate terrestrial organic matter. Ulm (2002:339) also noted that $\Delta \mathrm{R}$ values calculated from estuarine marine/ terrestrial archaeological pairs from central Queensland demonstrated a lack of consistency, which he attributed to estuarine-specific variation in terrestrial carbon input and limited exchange with the open ocean. Two known-age historic samples of Volachlamys singaporina, a filter-feeding bivalve from near the mouth of the Boyne River at Port Curtis (Table 1, location 31), gave divergent $\Delta \mathrm{R}$ results ( $7 \pm 60 \mathrm{yrs}$ and 117 $\pm 60 \mathrm{yrs}$ ) which may also reflect estuarine variability, though other seasonal oceanographic factors could be involved (see above).

\section{Change over time}

Paleoclimate reconstructions using banded coral core records have indicated that there is long-term marine reservoir variability in some regions of the Pacific (Dunbar and Cole 1996:5; Druffel and Griffin 1993). Archaeological studies (Deo et al. 2004; Ingram 1998; Reimer et al. 2002; Yoneda et al. 2001) have also demonstrated the importance of longer-term $\Delta \mathrm{R}$ evaluation. For archaeological shells, the age of death is determined by the dating of short-lived charcoal from pene-contemporaneous contexts. Unfortunately, few published archaeological shell/charcoal pairs can demonstrate irrefutable penecontemporaneity, in part because charcoal is rarely identified to short-lived species increasing the likelihood of inbuilt age (Allen and Wallace n.d.; Kennett et al. 2002), but also because of site disturbance and the misidentification of food shells. Recently, Jones et al. (2007) and Petchey et al. (2005) have used a Bayesian methodology that allows some uncertainty in the dated events to be incorporated in the calculation. This methodology incorporates all chronological data rather than just the paired marine/ terrestrial sample approach traditionally used (originally outlined by Stuiver and Braziunas 1993). This has met with initial success for the Santa Cruz Islands (Solomon Islands) and Watom Island, but is not a substitute for well provenanced and identified ${ }^{14} \mathrm{C}$ samples.

\section{Conclusion}

There are limited published pre-1950 $\Delta \mathrm{R}$ values for the islands that make up Oceania, and only a few conform to the prerequisites for $\Delta \mathrm{R}$ selection listed above. The most problematic values are those for deposit- feeders and other species that may incorporate sediment in their diets. These deposit-feeding shellfish should be avoided for both routine ${ }^{14} \mathrm{C}$ dating and $\Delta \mathrm{R}$ studies. Where several $\Delta \mathrm{R}$ values are avail able for a particular region, it becomes apparent that significant variation is possible over short distances. Consequently, it is recommended that the $\Delta \mathrm{R}$ value used for the calibration of archaeological shell samples belong to the same island. Annually banded corals clearly demonstrate seasonal and longer-term variation, but they are geographically few in number and may not directly relate to the same environmental conditions as the shell species selected from archaeological middens. The use of archaeological marine/terrestrial pairs would go a long way towards alleviating this problem. Unfortunately, there is only a handful of published $\Delta \mathrm{R}$ values calculated from archaeological marine/ terrestrial pairs, (Petchey and Addison in press) and the reliability of these values is currently hindered by problems of association and material suitability. 
Notes

1. A conventional radiocarbon age (CRA) is obtained from a radiocarbon measurement following the conventions set out by Stuiver and Polach (1977). A CRA must be calibrated to determine a calendar age. By convention, the symbol BP means 'conventional radiocarbon years before AD 1950', whereas the symbols cal BP or BC/AD are used to express calibrated radiocarbon ages.

2. For $\Delta \mathrm{R}$ calculated from historic shell, the date of collection should be before 1950 and preferably pre- 1850 . The 'bomb effect' shows up in coral core records from the north Pacific as early as 1956 (Konishi et al. 1982) and at the very earliest 1957 in the southern Pacific (Druffel and Griffin 1993, 1999; Toggweiler et al. 1991). Post-1850, anthropogenic effects (i.e. Seuss effect), such as dilution in 14C caused by fossil fuel burning has also been noted in both shell and coral records from across the Pacific (Druffel et al. 2001; Druffel and Griffin 1993, 1999; Guilderson et al. 2004; Hideshima et al. 2001) and may affect $\Delta R$ values on pre-1955 shells.

3. Algae grazers feeding on a living coral substrate should only incorporate very recent carbon, although this could vary where fossil and/or sub-fossil coral are present. Algal grazers that target species restricted to seaweed surfaces should not have this problem.

4. Of five coral cores collected from around Easter Island, only one exhibited distinct annual growth bands suitable for chronology development (Core Ovahe -97-1). This is attributed to the location of Easter Island at the environmental limits of coral tolerance (Beck et al. 2003; Mucciarone and Dunbar 2003:117, 122) and necessitates caution when using this $\Delta R$ value.

\section{Acknowledgements}

I would like to acknowledge the help of Gustav Paulay (University of Florida) and Mike Carson (International Archaeological Research Institute, Inc., Honolulu) for drawing my attention to $\Delta \mathrm{R}$ values not previously listed in the Marine Reservoir Database. Sean Ulm (University of Queensland) and Paula Reimer (Queen's University, Belfast) provided valuable discussion about $\Delta \mathrm{R}$. 


\section{Bibliography}

Allen, M. S. and R. Wallace. n.d. New evidence from the East Polynesian gateway: Substantive and methodological results from Aitutaki, Southern Cook Islands. Radiocarbon in press.

Anderson, A., T. F. G. Higham and R. Wallace. 2001. The radiocarbon chronology of the Norfolk Island archaeological sites. Records of the Australian Museum, Supplement 27:33-42.

Athens, J. S. 1986. Archaeological investigations at Tarague Beach, Guam. Report prepared for Base Civil Engineering, Andersen Air Force Base. International Archaeological Research Institute, Inc., Honolulu.

Bathen, K. H. 1968. A descriptive study of the physical oceanography of Kaneohe Bay, Oahu, Hawaii. University of Hawaii, Hawaii Institute of Marine Biology Technical Report 14.

Beck, J. W., L. Hewitt, G. S. Burr, L. Loret and F. T. Hochstetter. 2003. Mata ki Te Rangi: Eyes towards the heavens. Climate and radiocarbon dates. In J. Loret and J. T. Tanacredi (eds), Easter Island. Scientific Exploration into the World's Environmental Problems in Microcosm, pp 93-111. New York: Kluwer Academic/Plenum Publishers.

Beesley, P. L., G. J. B. Ross and A. Wells (eds). 1998. Mollusca: The Southern Synthesis. Fauna of Australia. Vol. 5. . Melbourne: CSIRO Publishing.

Broecker, W. S. and E. A. Olson. 1961. Lamont radiocarbon measurements VIII. Radiocarbon 3:176-204.

Burr, G. S., J. W. Beck, F. W. Taylor, J. Recy, R. L. Edwards, G. Cabioch, T. Correge, D. J. Donahue and J. M. O'Malley. 1998. A high-resolution radiocarbon calibration between 11,700 and 12,400 calendar years BP derived from Th-230 ages of corals from Espiritu Santo Island, Vanuatu. Radiocarbon 40:1093-1105.

Charpy, L. 2002. Exchanges between the atolls and the open ocean. The Institute for Research and Development. http://www.com.univ-mrs.fr/IRD/atollpol/fnatoll/ukatocea.htm.

Chen, C. W., D. Leva and W. Kimmerer. 1995. Circulation and the value of passage channels to water quality of Tarawa lagoon. In R. R. Abbott and J. Garcia (eds), Management plan for Tarawa Lagoon, Republic of Kiribati, Volume 111. Management Plan. Tiburon CA: Technical Report of BioSystems Analysis Inc.

Craib, J. L. 1993. Early occupation at Unai Chulu, Tinian, Commonwealth of the Northern Mariana Islands Indo-Pacific Prehistory Association Bulletin 13:116-134.

Deo, J. N., J. O. Stone and J. K. Stein. 2004. Building confidence in shell: Variations in the marine radiocarbon reservoir correction for the Northwest coast over the past 3,000 years. American Antiquity 69(4):771-786.

Druffel, E. R. M. 1987. Bomb radiocarbon in the Pacific: Annual and seasonal timescale variations. Journal of Marine Chemistry 45:667-698.

Druffel, E. R. M. 2004. Galapagos coral radiocarbon data. IGBP Pages/World Data Center for Paleoclimatology Data Contribution Seies \#2004-087. Boulder CO, USA: NOAA/NGDC Paleoclimatology Program. http://www.ncdc.noaa.gov/paleo/coral/galapagos.html

Druffel E. R. M. and S. Griffin. 1993. Large variations of surface ocean radiocarbon: Evidence of circulation changes in the southwestern Pacific. Journal of Geophysical Research 98(C11):20,249-59.

Druffel, E. R. M. and S. Griffin. 1999. Variability of surface ocean radiocarbon and stable isotopes in the southwestern Pacific. Journal of Geophysical Research 104(C10): 23,607-23,613.

Druffel, E. R. M., S. Griffin, T. P. Guilderson, M. Kashgarian, J. Southon and D. P. Schrag. 2001. Changes of subtropical North Pacific radiocarbon and correlation with climate variability. Radiocarbon 43(1):15-25.

Druffel, E. R. M., S. Griffin, J. Hwang, T. Komada, S. R. Beaupre, K. C. Druffel-Rodriguez, G. M. Santos and J. Southon. 2004. Variability of monthly radiocarbon during the 1760 's in corals from the Galapagos Islands. Radiocarbon 46:627-631. 
Dunbar, R. B. and J. E Cole. 1996. Annual records of tropical systems (ARTS). A PAGES/CLIVAR Initiative. Recommendations for Research. Kauai ARTS Workshop, Sept 1996. Pages Workshop report series 99-1. http://pangea.standford.edu/Oceans/ARTS/arts_report/arts_report_home.html.

Dye, T. 1994. Apparent ages of marine shells: Implications for archaeological dating in Hawaii. Radiocarbon 36:51-57.

Flament, P., S. Kennan, R. Lumpkin, M. Sawyer and E. D. Stroup. 1996. The Ocean Atlas of Hawaii. Department of Oceanography, School of Ocean and Earth Science and Technology, University of Hawaii. http://radlab.soest.hawaii.edu/atlas

Forman, S. L. and L. Polyak. 1997. Radiocarbon content of pre-bomb marine mollusks and variations in the ${ }^{14} \mathrm{C}$ reservoir for coastal areas of the Barents and Kara seas, Russia. Geophysical Research Letters 24:885-888.

Gillespie, R. 1977. Sydney University natural radiocarbon measurements IV. Radiocarbon 19:101-110.

Guilderson, T. P., D. P. Schrag, M. Kashgarian and J. Southon. 1998. Radiocarbon variability in the western equatorial Pacific inferred from a high-resolution coral record from Nauru Island. Journal of Geophysical Research 103(C11):24,641-24,650.

Guilderson, T. P., D. P. Schrag, E. Goddard, M. Kashgarian, G. M. Wellington and B. K. Linsley. 2000. Southwest subtropical Pacific surface water radiocarbon in a high-resolution coral record. Radiocarbon 42(2):249-256.

Guilderson, T. P., D. P. Schrag and M. A. Cane. 2004. Surface water mixing in the Solomon Sea as documented by a high-resolution coral ${ }^{14} \mathrm{C}$ record. Journal of Climate 17:1147-1156.

Heath, R. A. 1985. A review of the physical oceanography of the seas around New Zealand - 1982. New Zealand Journal of Marine and Freshwater Research 19:79-124.

Hideshima, S., E. Matsumoto, O. Abe and H. Kitagaawa. 2001. Northwest Pacific marine reservoir correction estimated from annually banded coral from Ishigaki Island, Southern Japan. Radiocarbon 43:473-476.

Higham, T. F. G. and A. G. Hogg. 1995. Radiocarbon dating of prehistoric shell from New Zealand and calculation of the $\Delta \mathrm{R}$ value using fish otoliths. Radiocarbon 37(2):409-416.

Hogg, A. G., T. F. G. Higham and J. Dahm. 1998. ${ }^{14} \mathrm{C}$ dating of modern marine and estuarine shellfish. Radiocarbon 40(2):975-984.

Hughen, K. A, M. G. L. Baillie, E. Bard, J. W. Beck, C. J. H. Bertrand, P. G. Blackwell, C. E. Buck, G. S. Burr, K. B. Cutler, P. E. Damon, R. L. Edwards, R. G. Fairbanks, M. Friedrich, T. P. Guilderson, B. Kromer, G. McCormac, S. Manning, C. Bronk Ramsey, P. J. Reimer, R. W. Reimer, S. Remmele, J. R. Southon, M. Stuiver, S. Talamo, F. W. Taylor, J. van der Plicht, and C. E. Weyhenmeyer. 2004. Marine04 Marine Radiocarbon Age Calibration, 0-26 Cal Kyr BP. Radiocarbon 46:1059-1086.

Ingram, B. L. 1998. Differences in radiocarbon age between shell and charcoal from a Holocene shell mound in Northern California. Quaternary Research 49:102-110.

Jones, M., F. Petchey, R. Green, P. Sheppard and M. Phelan. 2007. The marine $\Delta R$ for Nenumbo: A case study in calculating reservoir offsets from paired sample data. Radiocarbon 49:95-102.

Kennett, D. J., B. L. Ingram, J. R. Southon and K. Wise. 2002. Differences in ${ }^{14} \mathrm{C}$ age between stratigraphically associated charcoal and marine shell from the archaic period site of Kilometre 4, Southern Peru: Old wood or old water? Radiocarbon 44:53-58.

Konishi, K., T. Tanaka and M. Sakanoue. 1982. Secular variation of radiocarbon concentration in sea water: Sclerochronological approach. In E. D. Gomez (ed.), Proceedings of the Fourth International Coral Reef Symposium 1, pp 181-185, Marine Science Center. Manila: University of the Philippines.

Moberly, R. Jnr. 1963. Coastal Geology of Hawaii, Final report prepared for Dept. of Planning and Economic Development, State of Hawaii. Hawaii Institute of Geophysics, Report No. 41. Honolulu: University of Hawaii. 
Mucciarone, D. A. and R. B. Dunbar. 2003. Stable isotope record of El Niño-Southern Oscillation events from Easter Island. In J. Loret, and J. T. Tanacredi (eds), Easter Island. Scientific Exploration into the World's Environmental Problems in Microcosm, pp 113-132. , New York: Kluwer Academic/ Plenum Publishers.

Paulay, G., and A. Kerr. 2001. Patterns of coral reef development on Tarawa Atoll (Kiribati). Bulletin of Marine Science 69(3):1191-1207.

Petchey, F., M. Phelan and P. White. 2004. New $\Delta$ R values for the southwest Pacific Ocean. Radiocarbon 46:1005-1014.

Petchey, FJ, Addison DJ, in press. Radiocabon dating marine shell in Samoa: A new delta-R from knownage speciment. in: Addison DJ, Asaua TS, Sand C (eds), Recent Archaeology in the Fiji/WestPolynesia Region: Papers from the Archaeology of the Polynesian Homeland Conference. Dunedin: Otago University.

Petchey, F., R. Green, M. Jones and M. Phelan. 2005. A local marine reservoir correction value $(\Delta R)$ for Watom Island, Papua New Guinea. New Zealand Journal of Archaeology 26 (2004):29-40.

Phelan, M. B. 1999. A $\Delta$ R correction value for Samoa from known-age marine shells. Radiocarbon 41:99-101.

Pirazzoli, P. A, G. Delibrias, L. F. Montaggioni, J. F. Saliège, and C. Vergnaud-grazzini. 1987.

Vitesse de croissance latérale des platiers et évolution morphologique récente de l'atoll de Reao, Iles Tuamotu, Polynésie Française. Annales de l'Institut océanographique 63(1):57-68.

Reimer, P. J., F. G. McCormac, J. Moore, F. McCormick and E. V. Murray. 2002. Marine radiocarbon reservoir corrections for the mid- to late Holocene in the eastern subpolar North Atlantic. The Holocene 12(2):129-135.

Richmond, B. M. and P. S. Roy. 1986. Near shore sediment distribution and sand and gravel deposits in lagoon areas, northern Tongatapu, Tonga. CCOP/SOPAC Technical Report 63, June 1986.

Sikes, E. L., C. R. Samso, T. P. Guilderson and W.R. Howard. 2000. Old radiocarbon ages in the southwest Pacific Ocean during the last glacial period and deglaciation. Nature 405: 555-559.

Smith, R. 1999. Study for numerical circulation model of Abaiang Lagoon, Kiribati. SOPAC Preliminary Report 112.

Snelgrove, P. V. R. and C. A. Butman. 1994. Animal-sediment relationships revisited: Cause vs effect. Oceanography and Marine Biology: An Annual Review 32:111-177.

Southon, J, M. Kashgarian, M. Fontugne, B. Metivier and W. W-S. Yim. 2002. Marine reservoir corrections for the Indian Ocean and Southeast Asia. Radiocarbon 44:167-180.

Sparks, R. J., G. W. Drummond, G. W. Brailsford, D. C. Lowe, K. R. Lassey, M. R. Manning, C. B. Taylor and G. Wallace. 1992. Radiocarbon measurements in South Pacific ocean waters in the vicinity of the Subtropical Convergence zone. Radiocarbon 34:727-736.

Specht, J and C. Gosden. 1997. Dating Lapita pottery in the Bismarck Archipelago. Asian Perspectives 36(2):175-199.

Spennemann, D. H. R. and M. J. Head. 1998. Tongan pottery chronology, ${ }^{14} \mathrm{C}$ dates and the hardwater effect. Quaternary Geochronology 17:1047-1056.

Stearns, H. T. 1938. Geologic and topographic map of the Island of Oahu, Hawaii. Hawaii Commission on Water Resource Management 1:62,500. http://ngmdb.usgs.gov/ngm-bin/

Stearns, H. T. 1978. Quaternary shorelines in the Hawaiian Islands: Bernice P. Bishop Museum Bulletin 237:1-57.

Stuiver, M., G. W. Pearson and T. F. Braziunas.1986. Radiocarbon age calibration of marine samples back to 9000 cal yr BP. Radiocarbon 28:980-1021.

Stuiver, M., and T. F. Braziunas. 1993. Modelling atmospheric ${ }^{14} \mathrm{C}$ influences and ${ }^{14} \mathrm{C}$ ages of marine samples to 10,000 BC. Radiocarbon 35:137-189.

Stuiver, M. and H. A. Polach. 1977. Discussion: Reporting ${ }^{14} \mathrm{C}$ data. Radiocarbon 19:355-63. 
Summerhayes, G. R. 2001. Defining the chronology of Lapita in the Bismarck Archipelago. In G. R. Clark, A. J. Anderson and T. Vunidilo (eds), The Archaeology of Lapita Dispersal in Oceania, pp 25-38. Papers from the Fourth Lapita Conference, June 2000, Terra Australis 17. Canberra: Pandanus Books.

Tanaka, N., M. C. Monaghan and D. M. Rye. 1986. Contribution of metabolic carbon to mollusc and barnacle shell carbonate. Nature 320:520-523.

Toggweiler, J. R., K. Dixon and W. S. Broecker. 1991. The Peru upwelling and the ventilation of the South Pacific thermocline. Journal of Geophysical Research 96 (C11): 20,467-20,497.

Tomczak, M. and J. S. Godfrey. 2001. Regional Oceanography: An introduction. Version 1.0. Oxford: Elsevier Science Ltd. http://www.es.flinders.edu.au/ mattom/regoc/pdfversion.html

Ulm, S. 2002. Marine and estuarine reservoir effects in central Queensland, Australia: Determination of $\Delta R$ values. Geoarchaeology: An International Journal V17(4):3119-348.

Xie, S. P., W. T. Liu, Q. Liu and M. Nonaka. 2001. Far-reaching effects of the Hawaiian Islands on the Pacific ocean/atmosphere. Science 292:2057-2060.

Yoneda, M., M. Hirota, M. Uchida, K. Uzawa, A. Tanaka, Y. Shibata and M. Morita. 2001. Marine radiocarbon reservoir effect in the western north Pacific observed in archaeological fauna. Radiocarbon 43:465-471. 